\title{
Business Process and shop floor Re-Engineering
}

DOUMEINGTS. MALHENE

LAP / GRAI - University Bordeaux 1

351 cours de la Libération 33405 TALENCE CEDEX - FRANCE

Tel : (33) (0) 556846530 - Fax : (33) (0) 556846644

E-mail :doumeingts@lap.u-bordeaux.fr

\begin{abstract}
For companies, Business Process Re-engineering (BPR) is becoming a technique to attaining a competitive advantage. But BPR is too often related to specific process while it should ensure a global performance by covering multi-processes. By combining local view with global one, and moreover, by combining physical view of the enterprise with its associated decisional part, GRAI approach allows to introduce the Business System Re-engineering (BSR) concepts.

The approach has been successfully applied in a lot of industrial experiments. One of the most recent one has contribute to demonstrate the efficiency of the approach in the domain of Shop-floor.
\end{abstract}

\section{Key words}

Business System Re-engineering, Methodology, GRAI approach, Shop-floor.

\section{INTRODUCTION}

Companies are under increased pressure today to improve performance while being customer oriented. The high competition in a global international market and the decrease of product life cycles have led manufacturing enterprises to increase their capability, to react rapidly, in coherence with the objective focusing on their core-business.

BPR is an approach to re-design one or several processes of a company in order to improve its performances. This can underlies a complete re-organization of the activities which compose the process and so, a modification of its way of running or of its objectives. Different existing approaches for improving these Business Processes help companies to understand how the different functions or processes are acting. Nevertheless most of them are focusing on the improvement of individual processes (Figure 1). 


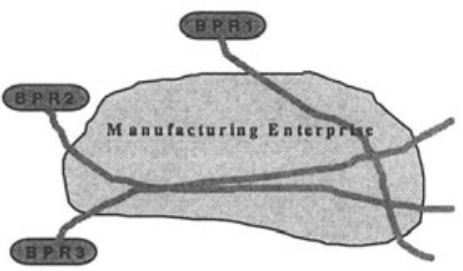

Figure 1 Business Process Re-engineering

Now, global performance is not a set of local business performances, and improving a local process does not underlie the fact that the performance of the whole system is improved. It is absolutely necessary to improve each business process according to the overall manufacturing enterprise performances, and not only according to the optimization of each process individually.

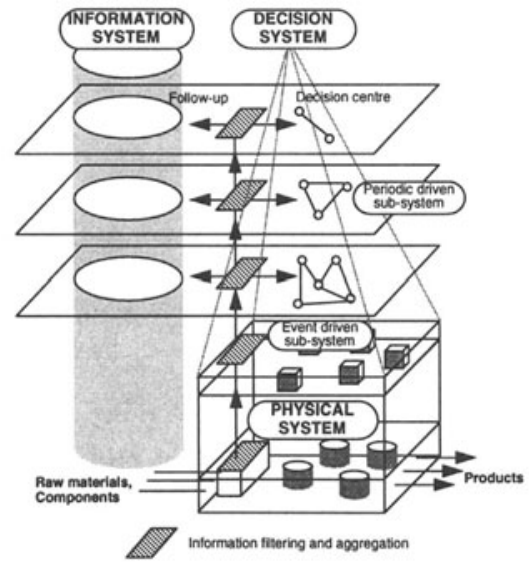

Figure 2 The GRAI conceptual model of the manufacturing system

This is the key idea of the GRAI approach which is based on the GRAI reference model. This model includes as well a global view of the system as a local view which have the same structure. The model identifies three systems in the manufacturing system : the physical system, the decision system and the information system (Figure 2).

The physical system has to transform raw materials, components, into the output Products through the resources. All along this transformation process, the physical system sends back the information, related to the process performance back, to the management system. This feedback information allows the management system to adjust its control.

The Decision System (DS), split up into decision making levels, according to several criteria, each level composed of one or several Decision Centers (DC).

The information system contains all information needed by the DS : it must be structured in an hierarchical way according to the DC structure.

The following part of the document describes a recent application of the GRAI approach for the re-engineering of a shop floor department in the most important French company in the domain of defense industry. Through this application, we will describe why GRAI approach is more powerful than traditional BPR approaches by ensuring in one hand Business Process 
integration through a multi-process improvement and in the other hand the coherence between physical part of the enterprise and its related decisional part

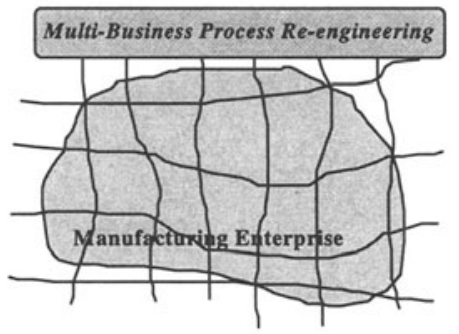

Figure 3 Multi-Business Process Re-engineering

Thus, instead of BPR we will use the concept of Business System Re-engineering (BSR) (Figure 3).

\section{PRESENTATION OF A CASE STUDY}

The studied shop floor department belongs to an important French Defense company. It works in the domain of mechanical industry and in the past, was acting as a subcontractor for the various divisions of the company. Due to the tremendous changes in this industrial sector, the re-structuring of the workshop and the re-orientation of the activities of this workshop was absolutely necessary in order to find new markets. Further more, important financial losses was questioning its future.

The context of the study was delicate because the whole enterprise was in total restructuring, and the social context was difficult. After different applications of re-engineering studies which triggered few fruitless changes during two years, the majority of the employees was skeptical before the application of GRAI approach.

For this structural and psychological reasons, it has been decided to perform the Business System Re-engineering in combination with a training action.

The study performed with the GRAI approach was organized in three steps :

1. existing situation analysis : the modelling phase,

2. specification of the new shop floor department : the design phase,

3. implementation process and planning : the action planning.

The application of GRAI is also structured in terms of participants. It requires:

- a project board composed by the top management of the shop floor department (in fact, the manager of the shop floor department and the Director of the whole Manufacturing System). The goals of this group are to give the objectives of the study, and to orient the study according to the results of the main phases,

- a synthesis group composed of the main decision makers of the shop floor department : Purchasing, Engineering, Manufacturing, Supplying, Quality and Maintenance functions (8 persons). This group has to give global information, to follow the development of the study, and to validate the results of the various stages. Their technical abilities and their suggestions will be used to guide the design of the new system. This group has in charge of analyzing and modeling the 
overall organization of the workshop : physical system, main DC, relations between functions, hierarchical structure and coherence of the Production Management System (PMS).

- a specialist/analyst, whose job is, in particular, to collect all the data needed for the various phases, and to elaborate the proposals to the synthesis group. An analyst from the company was helping the specialist/analyst.

- the interviewees group which has to provide more details on specific parts of the shop floor department.

After the modelling phase, specific groups may be defined, according to the specific solutions to be developed.

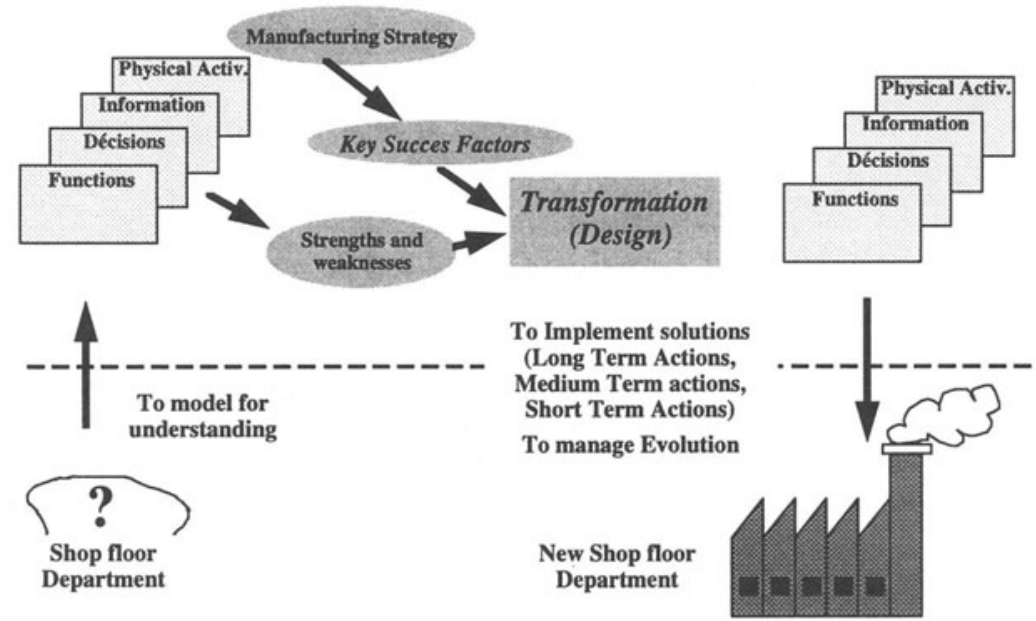

Figure 4 Overall re-engineering process in the GRAI approach

The main advantages of this approach are the following.

First, there is a set of formalisms, which allows the user to perform an integrated model of the shop floor department, according to the three sub-system identified in the conceptual model, plus the functional view. The GRAI grid gives an overview of the decisions made in the various functions. Through the links between these decisional activities, it is possible to study the effective integration of these various functions. Further more, for all Decision Centers, the activities to be performed are analyzed and designed according to the structure and the organization of the physical system (the controlled system). This ensures the coherence between the decisional system and the physical one. Finally, the information system is structured according to the requirements of all the Decision Centers.

Second, the structured approach provides an efficient guideline to manage the project (step by step approach) and it also ensures the validity of the model which are performed (top-down analysis followed by a bottom up one).

These two main advantages give to the GRAI approach a real power to perform BSR in an integrated way. 


\section{DESCRIPTION OF THE MAIN RESULTS}

\subsection{The modeling phase}

The main objective of the modeling phase of GRAI approach is to determine the improvement tracks to be studied during the design phase. For that purpose, the study was organized in three steps :

1. Training to modeling techniques,

2. Application to the shop floor department,

3. Analysis of the performed models to evaluate the shop floor department situation.

The modeling phase provides a set of models and the functional view of the system :

- functional view of the workshop (Idefø formalisms),

- physical model of the workshop (Idefø formalisms),

- decisional model of the management structure (GRAI grid and GRAI nets formalisms),

- information system model (Entity/Relation formalisms).

The models of the shop floor department was elaborated using the knowledge of the Synthesis Group. In parallel, we have created a group of Foremen in order to perform the training at all levels and also to collect complementary information.

Two examples of model are presented figure 5 and figure 6 :

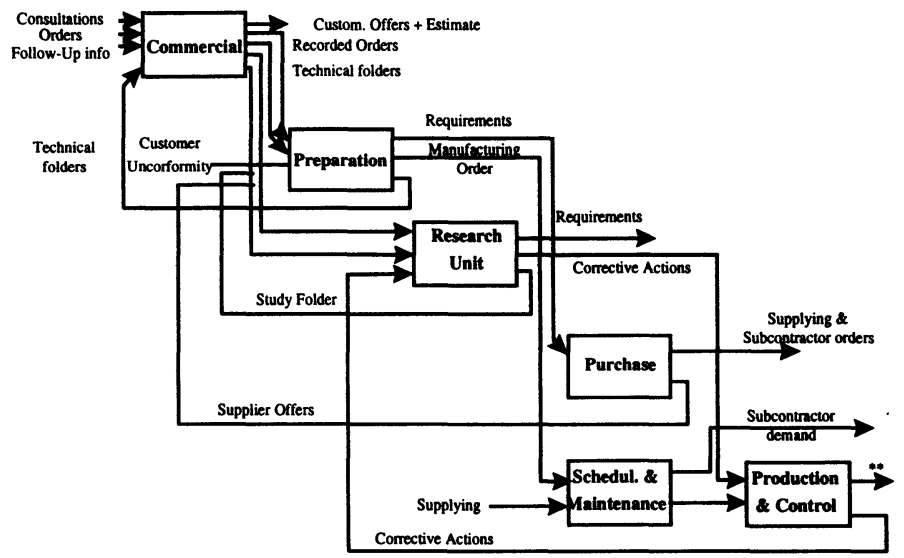

Figure 5 Example of the workshop functional model

These both models were elaborated from the knowledge of the Synthesis Group. Such a topdown approach allows to focus on the real problems, and it avoids to be swamped by a mass of irrelevant detail, which may cost time and money.

This top-down phase is completed by a bottom-up phase in order to collect information on the floor by interviews. But this complementary collect is done in the frame of the initial models performed through the top-down phase.

In this particular application, we have used the training session with the foremen to collect additional information. 


\begin{tabular}{|c|c|c|c|c|c|c|c|c|c|c|}
\hline 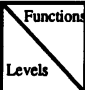 & $\begin{array}{l}\text { Extermal } \\
\text { Info. }\end{array}$ & \begin{tabular}{|c|} 
To Manage \\
Commercial \\
MC
\end{tabular} & \begin{tabular}{|c|} 
To Manage \\
Engineering \\
ME
\end{tabular} & $\begin{array}{l}\text { To Manage } \\
\text { Preparation } \\
\text { MPrep }\end{array}$ & $\begin{array}{c}\text { To Manage } \\
\text { Products } \\
\text { MP }\end{array}$ & $\begin{array}{c}\text { To Plan } \\
\text { PL }\end{array}$ & $\begin{array}{c}\text { To Manage } \\
\text { Resources } \\
\text { MR }\end{array}$ & $\begin{array}{c}\text { To Manage } \\
\text { Quality } \\
\text { MQ }\end{array}$ & $\begin{array}{l}\text { To Manage } \\
\text { Gen. Serv. } \\
\text { MGS }\end{array}$ & $\begin{array}{c}\text { Internal } \\
\text { Info. }\end{array}$ \\
\hline $\begin{array}{l}\mathrm{H}=1 \text { Year } \\
\mathrm{P}=1 \text { Year }\end{array}$ & $\begin{array}{l}\text { Budget } \\
\text { (per } \\
\text { section) }\end{array}$ & $\begin{array}{l}\text { Commercial } \\
\text { forecessting }\end{array}$ & & & & & & & & \\
\hline $\begin{array}{l}\mathrm{H}=1 \text { Month } \\
\mathrm{P}=1 \text { Month }\end{array}$ & \begin{tabular}{|c|} 
Budget \\
Turnover \\
Order book \\
Strenght \\
\end{tabular} & & & & & $\begin{array}{l}\text { Compare } \\
\text { yesults to } \\
\text { budget }\end{array}$ & & $\begin{array}{l}\text { Resnilus } \\
\text { compared to } \\
\text { the quality } \\
\text { obiectives }\end{array}$ & & $\begin{array}{l}\text { Production } \\
\text { follow-up } \\
\text { (PSC } \\
\text { ACCEPD }\end{array}$ \\
\hline $\begin{array}{l}\mathrm{H}=1 \text { Year } \\
\mathrm{P}=2 \text { Weeks }\end{array}$ & $\begin{array}{r}\text { Budget } \\
\text { C }\end{array}$ & $\begin{array}{l}\text { Commercin } \\
\text { Reportine } \\
\text { Gat Paris) }\end{array}$ & & & & & & & & $\begin{array}{l}\text { Order book } \\
\text { Prospection } \\
\text { in progress }\end{array}$ \\
\hline $\begin{array}{l}H=1 \text { Week } \\
P=1 \text { Week }\end{array}$ & $\begin{array}{l}\text { Supplying } \\
\text { receipt } \\
\text { Customer } \\
\text { modif. }\end{array}$ & $\begin{array}{c}\text { commercen } \\
\text { results } \\
\text { exnluntion }\end{array}$ & & & & $\begin{array}{l}\text { analysis/ } \\
\text { Weekly } \\
\text { planning }\end{array}$ & $\underbrace{\text { Adjust }}_{\text {capacity }}$ & & & PSC \\
\hline $\begin{array}{l}\mathrm{H}=1 \text { Woek } \\
\mathrm{P}=1 \text { Day }\end{array}$ & $\begin{array}{l}\text { Customer } \\
\text { estimate } \\
\text { proposition }\end{array}$ & $\begin{array}{l}\text { ADV order } \\
\text { uking } \\
\text { concertation }\end{array}$ & $\begin{array}{c}\text { Surdy } \\
\text { Launching }\end{array}$ & $\begin{array}{l}\text { Prepartion } \\
\text { launching }\end{array}$ & $\begin{array}{l}\text { chpplying } \\
\text { check, } \\
\text { Supplier }\end{array}$ & $\begin{array}{l}\text { Adjsut load } \\
\text { foreman }\end{array}$ & & & & $\begin{array}{l}\text { Updating } \\
\text { PSC }\end{array}$ \\
\hline
\end{tabular}

Figure 6 Example of the workshop decisional model

The GRAI oriented evaluation is performed on the following aspects :

- production management structure (decisional level and functional decomposition),

- coordination principles (decision frames, information flows),

- production flow analysis (physical system organization).

Based on this frame and on the resulting models, strengths and weaknesses have been identified. In particular the analysis of the decisional model has highlighted different problems for examples :

- there is no long term and medium term planning (it is detected on the GRAI grid),

- the yearly budget objective is not decomposed into operational objectives which leads to the fact that it is difficult to elaborate a Master Production Scheduling,

- the supplying level can not be efficient without a master production scheduling.

This evaluation has also been performed according to the business planning of the company. However, this business planning was not precise enough, and the information was not enough disseminated.

Finally, this step has allowed to identify the weaknesses of the studied workshop :

- lack of long term and medium term decision for anticipation,

- low flexibility and lack of anticipation due to a short term event driven management,

- insufficient cost evaluation and no meeting of lead time,

- concept of contract not enough used.

The strengths of the system have also been highlighted :

- real capacity for adaptation and reaction,

- good technical know-how,

- high quality product level,

- important human investment.

To improve the competitiveness of the workshop, seven improvement tracks have been proposed based on the evaluation of the weaknesses and after discussions with the Synthesis Group :

- strategic orientation and commercial actions,

- structuring of the physical system, 
- organization of the "Scheduling department",

- implementation of a hierarchical planning system,

- product quality control definition,

- tools to support customer order engineering,

- training on Benchmarking procedures in order to improve some Business Processes.

\subsection{The design phase}

Before to start the design phase, the business planning of this workshop has been collected. This business planning was deduced from a market analysis and also from the evaluation of the strong points of the physical system (products and processes).

The design phase objectives was to eliminate the weaknesses, to look for practical solutions and to define the planning to implement the selected solutions.

The organization of this phase has been performed according to the 7 improvements tracks. For each track, a working group has been created, with participants from the both groups : the Synthesis Group, and the Foreman Group.

For each group, the following approach has been used :

- detailed analysis of the identified problems,

- analysis of existing studies and solution proposal,

- feasibility study,

- selected solution definition,

- proposal for an implementation planning.

Also, to ensure the overall coherence of the results, various meeting of the synthesis group were organized.

The results of the design phase is a global model describing the organization of the workshop, based on the conclusions of each working group. This model specifies for the three sub-systems (Physical, Decisional and Informational) the structure, the relations between the various functions of the shop floor department, and the responsibilities to be allocated.

\section{Physical system}

Based on the evaluation of the current situation, and based on the business planning, a product oriented organization has been selected. A detailed analysis has shown that the current available machine-tools were sufficient to ensure the re-organisation of the production cells (Figure 7).

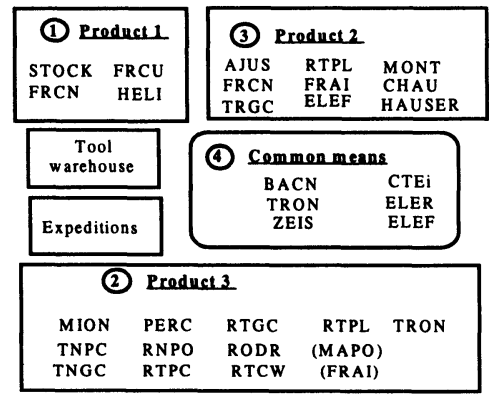

Figure 7 Production cell re-organisation 
A layout has been proposed, taking into account the technical constraints related to specific machines. One constraint has led us to identify one common cell for the last activities of some manufacturing processes (especially quality checking activities).

Training requirements and the new team organization has also been defined.

\section{Decisional system}

The interest of the GRAI approach is to allow an integrated modeling. So, based on the structure of the physical system and based on the hierarchical planning principles, we have specified the decisional structure of the PMS. From this decisional structure, the various responsibilities in each function have been defined precisely (Figure 8).

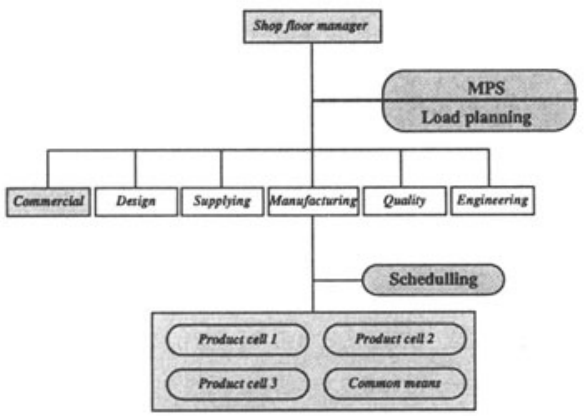

Figure 8 Function responsibilities regarding Production Management System

In this structure (Figure 9), the three basic planning levels and the relations between the various functions have been defined.

The detailed description of each planning level is based on the physical system, as it is seen by this level.

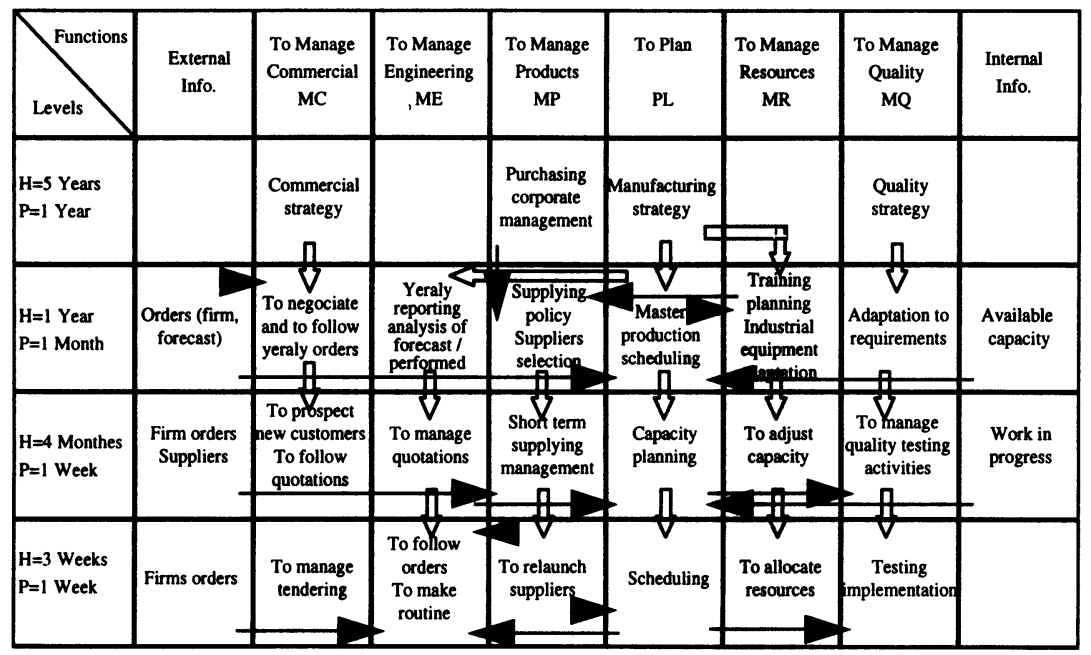

Figure 9 The GRAI grid : the decisional structure of the Production Management System 


\section{Information system}

The Information System was deduced from the Physical and the Decisional Systems including some complementary collect of information. However, after the modeling phase, it appeared that it was necessary to implement a scheduling system, because of the new environment (customer order driven activity, important amount of work-orders, needs for simulation to evaluate lead-times), and also because the existing system was supposed to stop at the end of the following year.

So a specification book has been written. Three suppliers were contacted, and a demonstration of each selected tool has been organized for the end users.

\subsection{Actions Plan}

The overall result of this design phase is a set of organization principles and technical solutions. Such a result is not sufficient for a manufacturing manager, it is important to define how and when the solutions would be implemented. The elaboration of the Actions Plan aims at preparing the implementation of these solutions.

It consists in specifying a list of actions, with the related required investment, the responsible person, and the scheduling of the various steps.

These actions were defined according three horizons :

1. short term actions ( 1 month horizon)

2. medium term actions ( 2 to 18 months horizon)

3. long term actions (more than 18 month horizon).

\section{CONCLUSION}

During this study, a BSR has been performed on the whole manufacturing enterprise. Most of the individual business processes have been studied : customer order processing, workshop control, quality checking, customer order engineering processes, long term management process, product manufacturing processes, etc. All these processes have been designed in a coherent way, based on the GRAI approach, which allowed to relate all these processes.

Also, based on this integrated design, the manager of the workshop succeed in discussing about the CAPM to be implemented. At the beginning, the company top management was thinking about one software for all the workshops of the company ; a MRP based software. Finally, in this workshop, they have selected a simple scheduling package (specification book already mentioned) which is more relevant for their type of production (specific tooling in three main areas).

Three months after the end of the application, the workshop had increased its turn over $(\approx 10 \%)$ and many improvements have been implemented (level of customer service rate, number of firm orders / Number of quotations).

This study which is exemplary, has supported the application of GEM (GRAI Evolution Methodology) which is a methodology developed in the frame of the EUREKA TIME GUIDE project (TIME : Tools and Methods for Integration and for Management of the Evolution of Industrial Enterprises - GUIDE : GUIDing the Evolution). GEM is an extension of GRAI approach and aims at providing the industrial companies a methodological support to steer and to guide their long term evolution process, mainly through modeling techniques, Self-Audit capability and Benchmarking techniques. The figure 10 summarizes the main steps of the structured approach of GEM. 


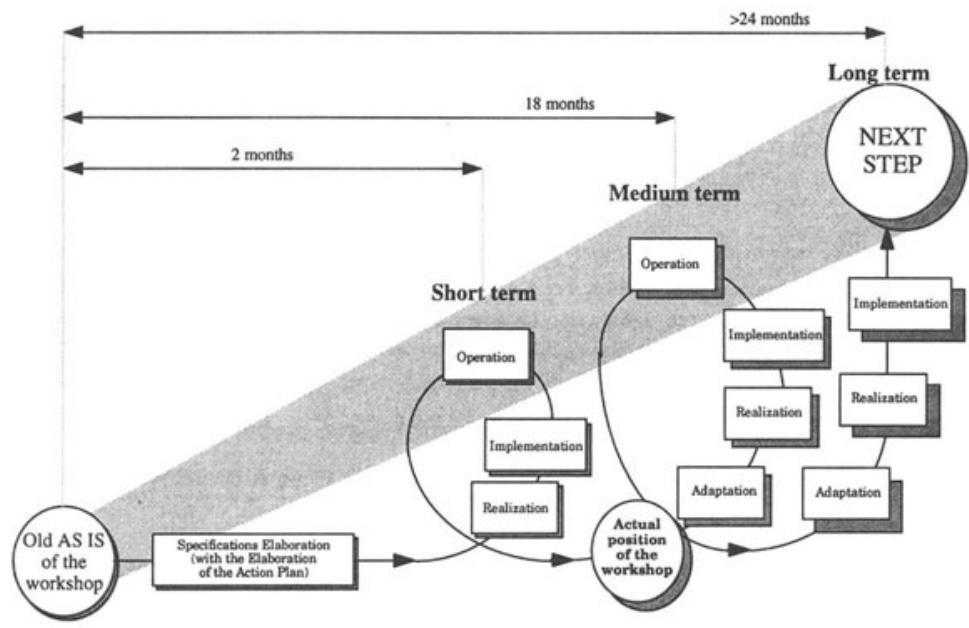

Figure 10 GEM structured approach

Industrials have already demonstrated their interest for GEM, particularly in the frame of the European ESPRIT program. The partners of the project REALMS II (Re-Engineering AppLication integrating Modelling and Simulation part II) which are ELVAL (Greece), BSW (Germany), NTUA (University of Athens - Greece), Siemens Nixdorf (Germany), IFAB (University of Karlsruhe - Germany) and the LAP/GRAI (France) have decided to use the methodology. The objective of the project is to finalize a methodology dedicated to the European SMI market through the application of GEM overall approach.

\section{RÉFÉRENCES}

CAM.I, Computer Aided Manufacturing International (1980), CAM-I -Architect's Manual: ICAM definition method, Computer Aided Manufacturing -International Inc. TEXAS, USA. 1980.

DOUMEINGTS G., MARCOTTE F., ROJAS H. : "GRAI Approach : a methodology for reengineering the manufacturing enterprise" . Re-engineering the enterprise - edited by $\mathrm{J}$. Browne and D. O'Sullivan - Chapman \& Hall - 1995

LE MOIGNE J.L. (1974) "La théorie du système général. Théorie de la modélisation."

MARCOTTE F.(1995) "Contribution à la modélisation des systèmes de production : extension du modèle GRAI" - Thèse de doctorat - Université Bordeaux I - Octobre 1995.

MELESE J. "Approche systémique des organisations : Vers l'entreprise à complexité humaine". Suresnes, Editions Hommes et Techniques, 1979, 158 p..

ROBOAM M. (1988) "Modèles de référence et intégration des méthodes d'analyse pour la conception des systèmes de production" - Thèse de Doctorat, Automatique, Université Bordeaux I - Juillet 1988. 